\title{
The role of nitrogen fixation in biogeochemical cycling in the subtropical North Pacific Ocean
}

\author{
D. Karl`, R. Letelier $\dagger$, L. Tupas ${ }^{\star}$, J. Dore ${ }^{\star} \neq$, J. Christian $\S \&$ D. Hebel ${ }^{\star}$ \\ * School of Ocean and Earth Science and Technology, Department of Oceanography, University of Hawaii, Honolulu, Hawaii 96822, USA \\ $\dagger$ College of Oceanic and Atmospheric Sciences, Oregon State University, Corvallis, Oregon 97331-5503, USA \\ $\ddagger$ Aquasearch Inc., 73-4460 Queen Kaahumanu Highway, Suite 110, Kailua-Kona, Hawaii 96740, USA \\ $\$$ Department of Oceanography, Dalhousie University, Halifax, Nova Scotia B3H 4J1, Canada
}

\begin{abstract}
Seven years of time-series observations of biogeochemical processes in the subtropical North Pacific Ocean gyre have revealed dramatic changes in the microbial community structure and in the mechanisms of nutrient cycling in response to large-scale ocean-atmosphere interactions. Several independent lines of evidence show that the fixation of atmospheric nitrogen by cyanobacteria can fuel up to half of the new production. These and other observations demand a reassessment of present views of nutrient and carbon cycling in one of the Earth's largest biomes.
\end{abstract}

Biological dinitrogen $\left(\mathrm{N}_{2}\right)$ fixation-the exclusively prokaryotic metabolic process responsible for converting the most abundant but relatively inert form of $\mathrm{N}$ into biologically available substrates-is the dominant mechanism for introduction of $\mathrm{N}$ into the biosphere; it approximates the total losses from microbiological denitrification on the global scale. Consequently, data on the quantitative role of $\mathrm{N}_{2}$ fixation in the oceans' nutrient budgets is of considerable scientific interest ${ }^{1}$. Although the presence of $\mathrm{N}_{2}$-fixing microorganisms and the associated nitrogenase activity in stratified, lownutrient oceanic habitats is well documented ${ }^{2-5}$, it has been difficult to obtain reliable estimates of $\mathrm{N}_{2}$-fixation rates, in part owing to spatial and temporal undersampling of the marine environment ${ }^{6-10}$. Most historical estimates have shown low rates of $\mathrm{N}_{2}$ fixation relative to the total $\mathrm{N}$ requirement for primary production in the sea. Consequently, most oceanic biogeochemical models simply ignore the potential flux from $\mathrm{N}_{2}$ fixation into these habitats ${ }^{11}$.

New production, defined as the amount of organic matter available for export from the surface ocean at steady state ${ }^{12}$, is thought to be constrained by the upward vertical flux of nitrate across the permanent thermocline ${ }^{13}$. The biologically mediated export of particulate organic matter from the surface ocean is a crucial term in the global carbon cycle because it represents a potential long-term sink for atmospheric carbon dioxide. Therefore, it is necessary to have an accurate understanding of new production mechanisms in the open-ocean regions where $70 \%$ of the total global export takes place ${ }^{14}$.

Here we summarize several independent data sets from the continuing Hawaii Ocean Time-series (HOT) research programme that collectively provide evidence for the importance of $\mathrm{N}_{2}$ fixation as a source of new $\mathrm{N}$ for the pelagic ecosystem at a station that is believed to be characteristic of the subtropical North Pacific Ocean ${ }^{15,16}$. Nitrogen-budget estimates suggest that $\mathrm{N}_{2}$ fixation may supply up to half of the $\mathrm{N}$ required to sustain the rate of the annual particulate $\mathrm{N}$ (PN) export from the euphotic zone. However, our observations indicate that this relatively high percentage of $\mathrm{N}_{2}$ supported production may represent a transient ecosystem state reflecting either natural oceanic variability or, perhaps, an unusual state established in response to the well documented decade-long shift in North Pacific climate ${ }^{17}$.

\section{Station ALOHA field data}

Since October 1988, a comprehensive suite of hydrographical and biogeochemical data have been collected at approximately monthly intervals to assess seasonal and interannual ocean variability at a time-series hydrostation (station ALOHA) located $100 \mathrm{~km}$ north of Oahu, Hawaii $\left(22^{\circ} 45^{\prime} \mathrm{N}, 158^{\circ} \mathrm{W}\right)$ in the North Pacific subtropical gyre $^{15}$.

One important, unexpected source of biogeochemical variability in this region has been the aperiodic appearance of large concentrations of the phototrophic, $\mathrm{N}_{2}$-fixing cyanobacterium Trichodesmium $\mathrm{spp}^{10}$. Long-term $(>1 \mathrm{yr}$ duration) increases in the abundances of Trichodesmium and other free-living and endosymbiotic $\mathrm{N}_{2}$-fixing microorganisms may be a manifestation of extended changes in the subtropical habitat ${ }^{18}$ induced by the El Niño/Southern Oscillation (ENSO). It has been proposed that this additional source of new nitrogen to the pelagic ecosystem has driven the North Pacific subtropical gyre from a nitrogen- to a phosphorus-controlled state $^{18}$ : we report here ecosystem data, collected over a 7 -year period, that support this hypothesis.

Our evidence of substantial $\mathrm{N}_{2}$-supported new and export production is derived from several independent measurements and data syntheses, including: (1) Trichodesmium population abundances and estimates of their potential rates of biological $\mathrm{N}_{2}$ fixation; (2) assessment of the molar N:P stoichiometries of surfaceocean dissolved and particulate matter pools and development of a one-dimensional model to calculate $\mathrm{N}$ and $\mathrm{P}$ mass balances; (3) seasonal variations in the natural ${ }^{15} \mathrm{~N}$ isotopic abundances of particulate matter exported to the deep sea and collected in bottom-moored sediment traps; and (4) observations on the secular changes in soluble reactive $\mathrm{P}$ (SRP), soluble non-reactive $\mathrm{P}$ (SNP) and dissolved organic $\mathrm{N}$ (DON) pools during the period of increased rates of $\mathrm{N}_{2}$ fixation. Considered separately, none of these data sets provides conclusive evidence for the quantitative role of $\mathrm{N}_{2}$ fixation. But when these data sets are viewed together, in the context of other time-series observations, we consider that they fully support our conclusion about the significance of $\mathrm{N}_{2}$ fixation in the subtropical North Pacific Ocean.

\section{Trichodesmium abundances and $\mathbf{N}_{\mathbf{2}}$-fixation rates}

Although $\mathrm{N}_{2}$ fixation can occur in free-living and endosymbiotic cyanobacteria as well as in selected species of heterotrophic bacteria, the filamentous cyanobacterium Trichodesmium spp. is considered to be a dominant $\mathrm{N}_{2}$-fixing species in oligotrophic marine ecosystems $^{1,9,19}$. Using epifluorescence microscopy, we have quantified 
the abundance of Trichodesmium (T. thiebautii and T. erytheaum) at station ALOHA for a period of three years and have reported a significant increase in Trichodesmium spp. biomass in the upper portion $(0-45 \mathrm{~m})$ of the water column over this observation period ${ }^{20}$. Based on a conservative estimate of cell-specific $\mathrm{N}_{2}$ fixation of $2 \mu \mathrm{mol} \mathrm{N}_{2}$ fixed per mmol of cell $\mathrm{N}$ per hour for Trichodesmium samples previously collected in the North Pacific subtropical gyre ${ }^{21}$, we estimate that the Trichodesmium population is capable of supplying $51( \pm 26) \mathrm{mmol} \mathrm{N} \mathrm{m}^{-2} \mathrm{yr}^{-1}$. This value is equivalent to $\sim 50 \%$ of the PN export measured at station ALOHA for the period October 1988 to December 1995 (Table 1). Rates of $\mathrm{N}_{2}$ fixation estimated from direct measurements of nitrogenase activity (acetylene reduction) of isolated Trichodesmium colonies and free trichomes collected at station ALOHA during several cruises are consistent with the rates extrapolated from the much larger data set on Trichodesmium abundance measurements (Table 1). These rate estimates are probably conservative because they do not include the potential contributions from other species that are known to be present at station ALOHA, most notably Richelia intracellularis, which is found in symbiotic associations with the diatom Rhizosolenia spp. ${ }^{5}$, and the free-living cyanobacterium Synechococcus spp. ${ }^{22}$.

\section{N:P stoichiometry of dissolved and particulate material}

The assessment of quantitative relationships between $\mathrm{N}$ and $\mathrm{P}$ in dissolved and particulate matter pools provides a conceptual framework for studies of organic-matter production-remineralization and nutrient limitation in the $\mathrm{sea}^{23,24}$. During nutrient-sufficient conditions near maximal growth rate, the N:P molar ratio for organic-matter production in the ocean should converge on 16:1 (the Redfield ratio) ${ }^{24}$. Thus attainment of the predicted Redfield $\mathrm{N}: \mathrm{P}$ stoichiometry in natural environments suggests rapid growth rate and complete nutrient saturation ${ }^{24}$. Because both positive and negative deviations from this predicted cellular N:P stoichiometry occur during nutrient-limited microbial growth ${ }^{25}$, it is possible to use the $\mathrm{N}: \mathrm{P}$ ratio as a diagnostic ecosystem parameter.

During the first two years of the HOT programme (pre-ENSO), the mean $\mathrm{N}: \mathrm{P}$ ratio for suspended particulate matter in the upper $(0-100 \mathrm{~m})$ water column was 15.3 (standard deviation (s.d.) $=3.1$, $n=14$ ), a value that was not significantly different from the Redfield prediction of 16.0 (Fig. 1). The transient, elevated N:P ratios observed during summer 1989 may have been a direct consequence of the extensive Trichodesmium bloom reported for this region ${ }^{10}$. Since 1991, however, we observed an increase in the molar N:P ratio of suspended particulate matter to a value greater than the expected Redfield stoichiometry (Fig. 1); that is, the mean $\mathrm{N}: \mathrm{P}$ ratio for the period $1991-95$ is 21.0 (s.d. $=3.5, n=44$ ). Because selected species of cyanobacteria, including Trichodesmium, can grow with reduced cell quotas of phosphorus ${ }^{10}$, the ecosystem drifts out of a Redfield N:P balance en route to phosphorus limitation as the supply of new $\mathrm{N}$ shifts from a limiting flux of nitrate from below the euphotic zone to the inexhaustible pool of $\mathrm{N}_{2}$ that is dissolved in the surface waters of the ocean. This shift to $\mathrm{N}_{2}$-supported new and export production has significant consequences for biogeochemical cycling pathways and rates. The coherent temporal pattern observed for suspended $\mathrm{N}: \mathrm{P}$, with maxima in the summer periods, is consistent with enhanced bioavailability of $\mathrm{N}$ relative to $\mathrm{P}$ resulting from increased rates of $\mathrm{N}_{2}$ fixation during periods of maximum water-column stratification $^{18,26}$.

The observed N:P balance of the dissolved nutrient reservoir, and the stoichiometry of the exported particulate matter, can also be

Table 1 Selected nitrogen inventories and fluxes at station ALOHA during 1988-95

\begin{tabular}{|c|c|c|}
\hline Parameter and period & Method & Value* \\
\hline \multicolumn{3}{|l|}{ Inventories (mmol $\mathrm{N} \mathrm{m}^{-2}$ ) } \\
\hline $\begin{array}{l}\text { Nitrate }(0-100 \mathrm{~m}) \\
1988-95\end{array}$ & Chemiluminescence & \\
\hline Winter (Jan.-Mar.) & & $2.6( \pm 4.0$ \\
\hline Summer (Jul.-Sept.) & & $0.4( \pm 0.3$ \\
\hline Annual mean & & $1.0( \pm 2.2$ \\
\hline $\begin{array}{l}\text { TDN }(0-100 \mathrm{~m}) \\
1988-95\end{array}$ & UV photo-oxidation/colorimetry & $568( \pm 62$ \\
\hline $\begin{array}{l}\text { PN (0-100 m) } \\
1988-95\end{array}$ & High temperature combustion/gas chromatography & $32( \pm 9)$ \\
\hline
\end{tabular}

Fluxes $\left(\mathrm{mmolN} \mathrm{m}^{-2} \mathrm{yr}^{-1}\right)$

PN production

1988-95

PN export

1988-95

$\mathrm{N}_{2}$ fixation

Oct. 1988-Dec. 1992

$\mathrm{N}_{2}$ fixation

1990-92

$\mathrm{N}_{2}$ fixation

1988-95

$\mathrm{N}_{2}$ fixation

1992-93

$\mathrm{N}_{2}$ fixation 1988-95
${ }^{14} \mathrm{C}$ method, assuming Redfield C:N molar ratio of 6.6

$2,044( \pm 694)$

Free-drifting sediment traps deployed at $150 \mathrm{~m}$

$105( \pm 43)$

Trichodesmium abundance, assuming cell-specific $\mathrm{N}_{2}$-fixation rate $\dagger$

$51( \pm 26)$

Based on HOT program acetylene reduction measurements of nitrogenase activity converted into $\mathrm{N}_{2}$-fixation equivalents

$\mathrm{N}: \mathrm{P}$ mass balance (see Fig. 2 and text)

$31( \pm 18)$

$34( \pm 14)$

${ }^{15} \mathrm{~N}$ isotope balance (see Table 2 and text)

50

Range of independent estimates

TDN, total dissolved N; PN, particulate nitrogen.

*Mean values, along with our best estimates of uncertainty.

tBased on reported trichome abundances $\left(4.6 \times 10^{4}\left[ \pm 2.3 \times 10^{4}\right]\right.$ trichomes per $\mathrm{m}^{3}$ for $0-45 \mathrm{~m}$ depth stratum) and elemental composition of Trichodesmium (9.6 ng N per trichome) for station $\mathrm{ALOHA}^{18}$, and assuming a conservative, average specific rate of $\mathrm{N}_{2}$ fixation of $2 \mu \mathrm{mol} \mathrm{N}_{2}$ fixed per mmol cell $\mathrm{N}$ per hr (ref. 21).

¥Based on acetylene reduction rates of Trichodesmium spp. measured for colonies collected at station ALOHA in June 1990 and February 1991 , and in colonies and single trichomes collected at station ALOHA in August 1992 converted to $\mathrm{N}_{2}$-fixation rates assuming an ethylene-to- $\mathrm{N}_{2}$ ratio of 3 (ref. 40 ) and extrapolated total $\mathrm{N}_{2}$ fixation using temporal distribution of

Trichodesmium biomass measured at station ALOHA ${ }^{20}$ 
explained by the growth of $\mathrm{N}_{2}$-fixing microorganisms in the pelagic environment of the North Pacific. The average total dissolved $\mathrm{N}$ : total dissolved P pool ratio (TDN:TDP) for our 7-year data set is much greater than the expected Redfield ratio, indicating an accumulation of $\mathrm{N}$ relative to $\mathrm{P}$ (Fig. 1). The average dissolved $\mathrm{N}: \mathrm{P}$ ratios for the depth intervals $0-100 \mathrm{~m}$ and $100-200 \mathrm{~m}$ show coherent temporal trends that are distinct from those observed below the euphotic zone (Fig. 1). The large difference in the TDN:TDP ratios in the upper water column $(0-200 \mathrm{~m})$ at station ALOHA, compared to deeper values $(200-500 \mathrm{~m})$, indicates that there must be a net contemporaneous production of dissolved fixed $\mathrm{N}$ in the surface waters, relative to the large nutrient reservoir below the euphotic zone. During episodes of enhanced vertical mixing, the surface-water TDN:TDP ratio returns to a near-Redfield balance as

Figure 1 Time series of $\mathrm{N}$ and $\mathrm{P}$ analyses of dissolved and particulate matter, expressed as N:P (mol:mol) ratios, for dissolved matter (upper panel), suspended particulate matter (centre panel) and exported particulate matter (lower panel). The upper panel shows the 3-point running mean N:P ratios for 0-100 $\mathrm{m}(\bullet), 100-$

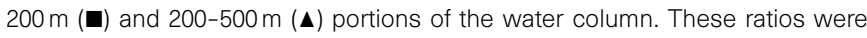
determined by integration (trapezoid rule) of discrete total dissolved nitrogen (TDN) and total dissolved phosphorus (TDP) measurements $(n=4-8)$ for each depth region, and calculation of a single TDN:TDP ratio from these inventory estimations. The centre panel shows the 3-point running mean ( \pm 1 standard deviation, s.d.) for the average suspended particulate N:P ratio measured in the upper portion (0-100 $\mathrm{m}$ ) of the water column on each cruise (depth-integrated particulate $\mathrm{N} \div$ depth-integrated particulate $\mathrm{P})$. The lower panel shows the 3 point running mean $( \pm 1$ s.d.) for the average $N: P$ ratio of the sediment-trapcollected particulate matter at the 150-m reference depth. Water samples were collected in polyvinylchloride bottles using standard shipboard procedures ${ }^{15}$. Subsamples for TDN and TDP concentrations were treated with high-intensity ultraviolet light, followed by automated colorimetric analysis ${ }^{39}$. Subsamples for suspended particulate $N$ analyses were screened through 202- $\mu \mathrm{m}$ Nitex then filtered through combusted, Whatman (GF/F) glass fibre filters followed by hightemperature combustion and detection of $\mathrm{CO}_{2}$ and $\mathrm{N}_{2}$ (ref. 35). Suspended particulate $P$ was measured by high-temperature sample ashing and autoanalysis ${ }^{40}$. Free-drifting sediment traps ${ }^{35}$ deployed at $150 \mathrm{~m}$ for an $\sim 3$-day period during each cruise were used to collect sinking particulate matter for the determination of export fluxes and for $\mathrm{N}$ and $\mathrm{P}$ elemental analyses, as above, except that $335-\mu \mathrm{m}$ Nitex pre-screening was used. The Redfield ratio ( $\mathrm{N}: \mathrm{P}=16)$ is represented by a dashed line in all three panels.
Figure 2 Role of $\mathrm{N}_{2}$ fixation as a source of new nitrogen as determined by the N-P mass-balance model (see text). The data shown are the monthly estimates of $\mathrm{N}_{2}$ fixation, expressed as a percentage of particulate nitrogen (PN) export for the 7-year HOT programme data set. The solid line is the 3-point running mean value. Cruises where the calculated percentage was $<0$ (that is, where $(\mathrm{N}: \mathrm{P})_{\text {out }}<(\mathrm{N}: \mathrm{P})_{\mathrm{up}}$ ) were treated as $0 \% \mathrm{~N}_{2}$ fixation for the purpose of calculating the 3-point running mean. The 7-year average $\mathrm{N}_{2}$ fixation at station ALOHA based on the N-P mass balance model is $32 \%$ of PN flux. deeper waters are injected into the euphotic zone (for example, in spring 1990, 1992 and 1995; Fig. 1). Conversely, prolonged stratification, as might be expected during frequent or intense ENSO periods ${ }^{18}$, affects the N:P stoichiometry of both dissolved and particulate matter pools in the surface $(0-100 \mathrm{~m})$ waters, and forces the ecosystem out of the expected Redfield balance (for example, March 1992-October 1994; Fig. 1).

The N:P stoichiometry of exported particulate matter collected at the $150-\mathrm{m}$ reference level is consistent with the trends already discussed for suspended and dissolved matter pools. Low N:P values that were observed following a deep mixing event during HOT-14 (spring 1990), and the sustained higher than Redfield-ratio export, recorded especially during the extended ENSO period, are among the coherent trends (Fig. 1).
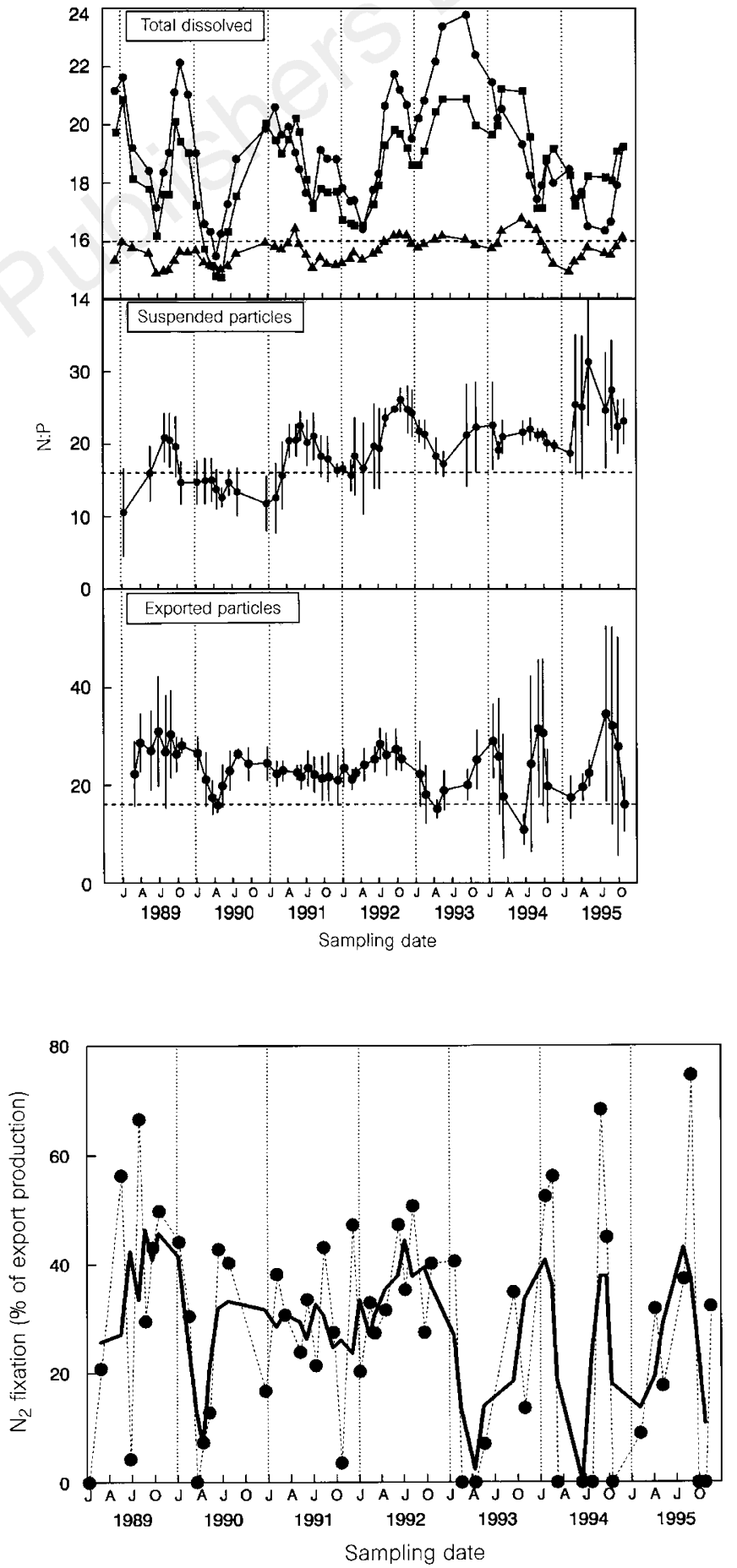
Below the euphotic zone, the exported organic matter is solubilized and remineralized by a variety of processes. It is important to reiterate that the relatively large intermediate-depth $(200-500 \mathrm{~m})$ reservoir of dissolved nutrients has an average $\mathrm{N}: \mathrm{P}$ ratio that is distinct from either the surface ocean pools or the sinking particulate matter collected at station ALOHA. However, the $\mathrm{N}_{2}$-fixation signatures that we now observe in the HOT programme data sets may be the result of a transient $\mathrm{N}-\mathrm{P}$ cycle decoupling, rather than being representative of the long-term $(>100$-year) steady state. Otherwise, we might expect the N:P ratios in the intermediate and shallow pools to converge because surface ocean export largely fuels nutrient regeneration at depth.

A simple two-component $\mathrm{N}$ source model was constructed to assess the potential role of $\mathrm{N}_{2}$ fixation using an upper water column $\mathrm{N}-\mathrm{P}$ mass-balance consideration. The operative assumption is that the only new $\mathrm{P}$ source term, as SRP, is due to upward eddy diffusion, and that this process and $\mathrm{N}_{2}$ fixation are the two potential source terms for new $\mathrm{N}$. When considering the total pool of organic matter (dissolved plus particulate), the $\mathrm{N}: \mathrm{P}$ ratio in the upper water column $(0-100 \mathrm{~m})$ at station ALOHA is relatively constant (mean total $\mathrm{N}$ : total $\mathrm{P}=18.9$, s.d. $=2.4, \quad n=59$ ) during our observation period (October 1988 to December 1995). Consequently an assessment of the role of $\mathrm{N}_{2}$ fixation can be made by considering the $\mathrm{N}: \mathrm{P}$ ratios of various potential sources and sinks as:

$$
\mathrm{N}_{\text {fix }} /\left[\mathrm{N}_{\text {fix }}+\mathrm{N}_{\text {up }}\right]=\left[(\mathrm{N}: \mathrm{P})_{\text {out }}-(\mathrm{N}: \mathrm{P})_{\text {up }}\right] /(\mathrm{N}: \mathrm{P})_{\text {out }}
$$

where $\mathrm{N}_{\text {fix }}$ and $\mathrm{N}_{\text {up }}$ are the rates of $\mathrm{N}_{2}$ fixation and upward eddy

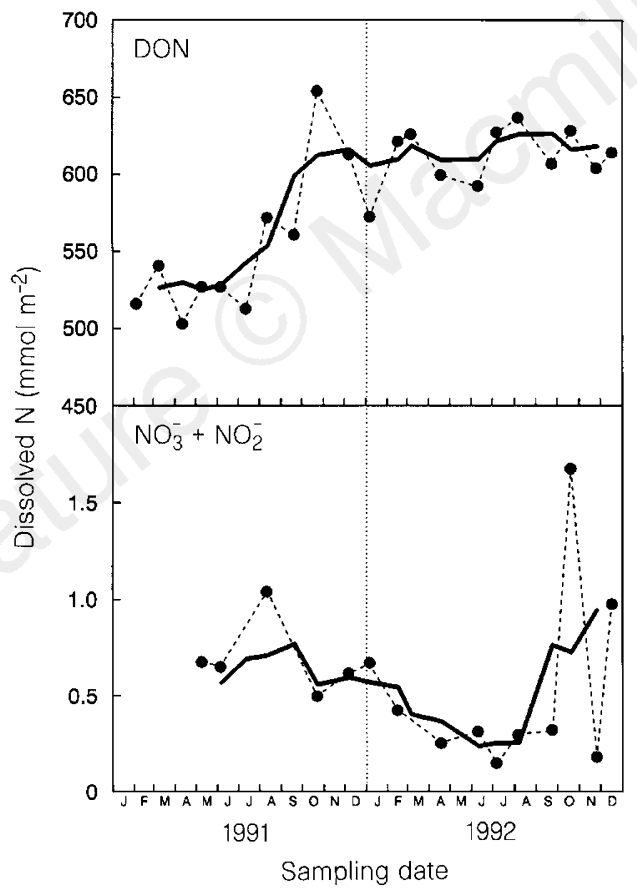

Figure 3 Dissolved nitrogen pool dynamics for the upper portion of the water column (0-100 m) at station ALOHA during the 1991-92 ENSO event. Top, dissolved organic nitrogen (DON) pool inventories; bottom, nitrate plus nitrite pool inventories. The solid line is the 3-point running mean value for each determination. Note the concentration scale differences; the majority of the total dissolved nitrogen (TDN) pool (>99\%) is DON. $\left[\mathrm{NO}_{3}^{-}+\mathrm{NO}_{2}^{-}\right]$was measured by chemiluminescence ${ }^{41}$, except for July 1991 and March 1992 when it was measured using standard autoanalyser techniques. DON was measured by difference (TDN $-\left[\mathrm{NO}_{3}^{-}+\mathrm{NO}_{2}^{-}\right]$) following high-intensity ultraviolet light treatment ${ }^{39}$. Each data point represents the $0-100 \mathrm{~m}$ depth-integrated inventory of $\left[\mathrm{NO}_{3}^{-}+\mathrm{NO}_{2}^{-}\right]$or DON measured on the approximately monthly cruises, generally from 6-7 individual water depths. diffusion of $\mathrm{N}$, respectively, and $(\mathrm{N}: \mathrm{P})_{\text {out }}$ and $(\mathrm{N}: \mathrm{P})_{\text {up }}$ are the $\mathrm{N}: \mathrm{P}$ ratios measured for particles exported from the euphotic zone and for the upward eddy-diffusive nutrient flux, respectively. Based on the results from station ALOHA (Fig. 1), that is, the mean $(\mathrm{N}: \mathrm{P})_{\text {out }}=23.3 \quad($ s.d. $=9.2, n=56)$ and the mean $(\mathrm{N}: \mathrm{P})_{\mathrm{up}}=15.6$ (s.d. $=0.6, n=61$ ), we estimate that $32 \%$ of the particulate $\mathrm{N}$ export, or $34 \mathrm{mmolN} \mathrm{m}^{-2} \mathrm{yr}^{-1}$, is supported by $\mathrm{N}_{2}$ fixation (Fig. 2 and Table 1). Significant temporal variations were observed in the estimated percentage of $\mathrm{PN}$ export from $\mathrm{N}_{2}$ fixation, with values ranging from $0 \%$ following deep winter mixing events (for example, 1990, 1993, 1994) to $>50 \%$ during periods of extended water column stratification (for example, 1989, 1992, 1994, 1995; Fig. 2). We also observed large interannual variations in the implied role of $\mathrm{N}_{2}$ fixation, with a sustained 2-year maximum during the extended ENSO period (1991-92) to a distinct minimum in 1994 (Fig. 2). These seasonal and interannual variations in the rates of $\mathrm{N}_{2}$ fixation are inextricably coupled to upper-ocean physical conditions and, ultimately, to ocean-atmosphere interactions.

We also observed a systematic change in the inventory of DON in the upper water column $(0-100 \mathrm{~m})$ that was especially evident during the 1991-92 ENSO event. The nitrate inventories were relatively constant and were, on average, $<1 \%$ of the TDN pool. There was no evidence of a winter-time nitrate injection as we have observed in non-ENSO years (Table 1). Nevertheless, there was a dramatic increase in DON in surface waters beginning in the summer of 1991 which was sustained until the end of 1992 (Fig. 3). A similar,

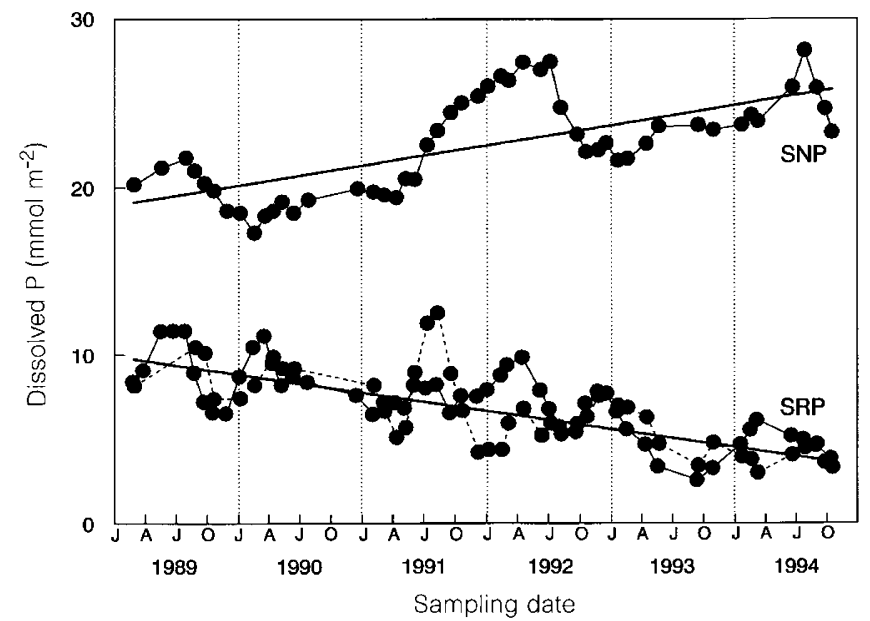

Figure 4 Dissolved phosphorus pool dynamics at station ALOHA for the period 1989-94, including the period corresponding to the extended 1991-92 ENSO event. The concentration of soluble reactive phosphorus (SRP) was measured both by a standard autoanalyser technique (data points connected by solid line) and by the high-sensitivity magnesium-induced co-precipitation (MAGIC) ${ }^{42}$ technique (data points connected by dashed line). Soluble non-reactive phosphorus (SNP) was measured by difference (TDP - SRP) following high-intensity ultraviolet light treatment ${ }^{39}$. Each data point represents the $0-100 \mathrm{~m}$ depth-integrated inventory of SRP or SNP measured on the cruises, generally from 6-7 individual water depths. The model I linear regression fit (bold line) for the MAGIC-SRP data set is: SRP $\left(\mathrm{mmol} \mathrm{m}^{-2}\right)=9.95-(0.003 \times$ days since 1 Jan. 1989). The model I linear regression fit (bold line) for the SNP data set is: SNP $\left(\mathrm{mmol} \mathrm{m}{ }^{-2}\right)=18.98+(0.003 \times$ days since 1 Jan. 1989$)$. 


\begin{tabular}{|c|c|c|}
\hline Sample source & $\begin{array}{c}\delta^{15} \mathrm{~N} * \\
(\% \circ)\end{array}$ & $\begin{array}{c}\text { Estimated } \\
\text { contribution from } \\
\mathrm{N}_{2}(\% \text { of total } \mathrm{N}) \dagger\end{array}$ \\
\hline \multicolumn{3}{|l|}{ Trichodesmium spp. } \\
\hline $\begin{array}{l}\text { Laboratory culture, } \\
\text { fixed N-free medium }\end{array}$ & -0.38 & 100 \\
\hline $\begin{array}{l}\text { Field collections } \\
\text { (HOT-9, } 0-1 \mathrm{~m})\end{array}$ & 0.41 & 93 \\
\hline \multicolumn{3}{|l|}{$\begin{array}{l}\text { Bottom-moored } \\
\text { sediment trap } \neq\end{array}$} \\
\hline $\begin{array}{l}\text { Winter export pulse } \\
\text { (Feb.) }\end{array}$ & 4.83 & 20 \\
\hline $\begin{array}{l}\text { Summer export pulse } \\
\text { (Jul.) }\end{array}$ & 1.53 & 75 \\
\hline Annual mean & 3.10 & 48 \\
\hline
\end{tabular}

All data measured in the Hawaii Ocean Time-series programme.

*Relative to air $\mathrm{N}_{2}$.

tBased on a two-source model: $\delta^{15} \mathrm{~N}=\left(\delta^{15} \mathrm{~N}_{\mathrm{a}}\right)(f)+\left(\delta^{15} \mathrm{~N}_{\mathrm{b}}\right)(1-f)$, where $f$ is the decimal fractional equivalent, $\mathrm{N}_{\mathrm{a}}$ and $\mathrm{N}_{\mathrm{b}}$ are theoretical values for $\mathrm{N}_{2}\left(\delta^{15} \mathrm{~N}=0\right)$ and $\mathrm{NO}_{3}^{-}\left(\delta^{15} \mathrm{~N}=6.5\right)$ based on values reported for the North Pacific Ocean (ref. 32).

¥A continuously recording, bottom-moored time-series sediment trap ${ }^{35,44}$ with traps positioned at $800,1,500,2,800$ and $4,000 \mathrm{~m}$ below the surface was used to collect the sinking particulate materials for the measurement of $\mathrm{N}$ isotope ratios. Perticulate matter from the 1500-m trap mater 1,500-m trap was concentrated onto tion with $\mathrm{Cu}$ and $\mathrm{CuO}$ to $\mathrm{N}_{2}$, and gas analysis using a Finnigan MAT-252 isotope-ratio mass spectrometer.

but transient, increase in DON was reported for the August 1989 Trichodemium bloom at station ALOHA ${ }^{10}$. Trichodesmium is known to release up to $50 \%$ of the $\mathrm{N}_{2}$ fixed as dissolved nitrogen ${ }^{27}$, in particular as the amino acid glutamate ${ }^{28}$. Compared to the 1990 annual mean DON of $474 \mathrm{mmol} \mathrm{N} \mathrm{m}^{-2}$ (s.d. $\left.=65 ; n=8\right)$, the 1991 and 1992 values $($ mean $=552$, s.d. $=49, n=10$ and mean $=612$, s.d. $=19, n=11 \mathrm{mmol} \mathrm{N} \mathrm{m}^{-2}$, respectively) represent a sustained accumulation of $69 \mathrm{mmol} \mathrm{N} \mathrm{m}^{-2} \mathrm{yr}^{-1}$ during this ENSO event. With an average $\mathrm{C}: \mathrm{N}$ ratio of $\sim 20$ for the dissolved organic matter at station $\mathrm{ALOHA}^{29}$, this DON accumulation could represent a net carbon sequestration of $\sim 1.4 \mathrm{~mol} \mathrm{C} \mathrm{m}^{-2} \mathrm{yr}^{-1}$ during the 1991-92 ENSO. This value exceeds the estimated $0.8-1.0 \mathrm{~mol} \mathrm{C} \mathrm{m}^{-2} \mathrm{yr}^{-1}$ annual air-to-sea flux of carbon dioxide for this region ${ }^{30}$, and emphasizes the potential role of $\mathrm{N}_{2}$ fixation in the $\mathrm{C}$ as well as the $\mathrm{N}$ cycle at station ALOHA. These DON accumulation results are consistent with the conceptual model previously presented for the ENSO-induced, $\mathrm{N}_{2}$-fixation-mediated alternation from $\mathrm{N}$ - to $\mathrm{P}$ limitation at station ALOHA ${ }^{18}$.

\section{Nitrogen-isotope composition of sinking particles}

The measurement of the natural abundance of ${ }^{15} \mathrm{~N}$ in particulate matter can be used as a diagnostic tracer of $\mathrm{N}$ sources for organic production. The nitrogen isotope ratio $\left({ }^{15} \mathrm{~N} /{ }^{14} \mathrm{~N}\right)$, expressed in the conventional $\delta^{15} \mathrm{~N}(\%)$ notation ${ }^{31}$, is potentially quite useful in our study because there is a large difference in $\mathrm{N}$ isotope ratio between the two different 'new' $\mathrm{N}$ sources $\left(\mathrm{N}_{2}=0 \%\right.$ versus $\mathrm{NO}_{3}^{-}=6-$ $7 \%$ o $)^{32}$. Although the exact $\delta^{15} \mathrm{~N}$ value of particulate matter is a complex result of the $\delta^{15} \mathrm{~N}$ value of the $\mathrm{N}$ source and the degree of isotopic fractionation during assimilation, the extremely low $\delta^{15} \mathrm{~N}$ values reported for Trichodesmium (approximately equal to the $\delta^{15} \mathrm{~N}$ of atmospheric $\left.\mathrm{N}\right)^{33}$ provide an unequivocal assessment of $\mathrm{N}_{2}$ fixation in our study area. Time-series measurements of the $\delta^{15} \mathrm{~N}$ of sinking particulate matter collected using a bottom-moored sediment trap deployed near station ALOHA reveal a systematic seasonal flux pattern that is consistent with our model of nitratebased export production following periods of winter mixing and $\mathrm{N}_{2}$-based export production during stratified summer conditions (Table 2). From the results of a simple two-source model, we estimate that $\mathrm{N}_{2}$ fixation supplies $48 \%$ of the total annual PN flux collected at the $1,500 \mathrm{~m}$ reference depth (Table 2 ). This value is equivalent to $50 \mathrm{mmol} \mathrm{N} \mathrm{m}^{-2} \mathrm{yr}^{-1}$ of $\mathrm{N}_{2}$-based new production, if a similar proportion holds for particulate matter exported at the base of the euphotic zone.

\section{Dissolved-phosphorus dynamics}

The dynamics of the dissolved phosphorus pool in the upper water column are also consistent with the suggested role of $\mathrm{N}_{2}$ fixation at station ALOHA. For example, the most readily available pool of phosphorus, SRP, decreased by more than $50 \%$ between 1989 and 1994 at an average rate of $1.1 \mathrm{mmol} \mathrm{P} \mathrm{m}^{-2} \mathrm{yr}^{-1}$, presumably in response to the shift from $\mathrm{N}$ to $\mathrm{P}$ limitation caused by increased $\mathrm{N}_{2}$ fixation (Fig. 4). By comparison, the near-surface $(0-100 \mathrm{~m})$ SNP pool, consisting largely of dissolved organic P compounds, increased over this same period at an average rate that was indistinguishable from the SRP decrease (that is, $1.1 \mathrm{mmol} \mathrm{P} \mathrm{m}^{-2} \mathrm{yr}^{-1}$ ). We interpret this shift from SRP to SNP to be the result of the production and accumulation of refractory $\mathrm{P}$ compounds that are not readily available to the plankton community. Direct measurements of microbial uptake of selected SNP compounds in Hawaiian waters indicate that SNP assimilation rates are an order of magnitude lower than those measured for orthophosphate (that is, SRP) when added at equivalent concentrations ${ }^{34}$. Extended periods of $\mathrm{N}_{2}$ fixation are expected to favour the selective removal of SRP and the selective accumulation of SNP, exactly the pattern that we observe at station ALOHA (Fig. 4).

During the period when SNP was accumulating in the upper water column $(0-100 \mathrm{~m})$, there was a corresponding increase in DON that was especially evident during the ENSO period (Fig. 3). The molar N:P ratio of the accumulating dissolved pool during 1991-92 is 63, nearly four times greater than the Redfield ratio. We interpret these coupled N-P nutrient dynamics (SRP decrease, SNP and DON increases and non-Redfield dissolved-matter accumulation) at station ALOHA to be the result of an uncoupling in the input of $\mathrm{N}$ versus $\mathrm{P}$ into the pelagic ecosystem. This uncoupling is consistent with an increase in cyanobacterial $\mathrm{N}_{2}$ fixation over the period of study. It is also informative to point out that during the period of DON accumulation, total autotrophic production (measured using ${ }^{14} \mathrm{C}$ techniques) increased without a concomitant increase in particulate matter ${ }^{18}$ while the sediment trap PN export decreased relative to the 7 -year average ${ }^{18,35}$. These results suggest that $\mathrm{N}_{2}$-supported new production pathways may also alter the mechanics of nutrient export from a predominantly particulatematter export to one where dissolved-matter export processes may become more important.

\section{Station ALOHA nitrogen budget}

We have compiled a budget for our time-series station based on various measured and derived fluxes of nitrogen. From these independent analyses, we conclude that $\mathrm{N}_{2}$ fixation may contribute up to half of the $\mathrm{N}$ required to sustain total annual export in the oligotrophic North Pacific Ocean (Table 1). There are at least two significant consequences of these results. First, it seems that the process of $\mathrm{N}_{2}$ fixation is an important source of 'new' $\mathrm{N}$ (as defined by Dugdale and Goering ${ }^{36}$ ) at station ALOHA and, probably, for the oligotrophic North Pacific subtropical gyre as a whole, especially during the 1991-92 ENSO period. Whether this temporal coherence with ENSO is a direct cause-and-effect relationship ${ }^{18}$ cannot be determined from the available data sets. Because nitrogenase requires $\mathrm{Fe}$ as a cofactor ${ }^{37}$, the availability of this and other essential trace nutrients may also exert a control on ambient rates of $\mathrm{N}_{2}$ fixation. Direct measurements of dissolved Fe at station ALOHA indicate the presence of non-limiting concentrations $(0.2-1.0 \mathrm{nM}$; ref. 38 and C. Measures, personal communication). The potential interactions of $\mathrm{Fe}$ deposition at the surface with $\mathrm{N}_{2}$-fixation rates and the attendant biogeochemical processes discussed here provides a basis on which to examine climate regimes. Second, it seems that phosphorus pool dynamics may ultimately control new and export 
production at station ALOHA, and probably in the subtropical North Pacific Ocean as a whole, during periods of enhanced $\mathrm{N}_{2}$ fixation. This revised view of the control of organic-matter production processes in possibly the largest continuous biome on Earth may require other changes in our assessment of global biogeochemical cycles. For example, if our conclusion about the role of cyanobacterial $\mathrm{N}_{2}$ fixation in new and export production is correct, we predict that new $\mathrm{N}$ inputs to these low-nutrient habitats may be more dependent upon the relaxation of upper-ocean mixing (selection for $\mathrm{N}_{2}$-fixing microorganisms) than on increased atmosphereforced mixing as is presently considered in new-production models. Furthermore, our results suggest a previously undetected seasonal variability in sources of new $\mathrm{N}$, as we have documented with the $\delta^{15} \mathrm{~N}$ data set derived from sediment-trap data. This altered view of biogeochemical dynamics in the subtropical North Pacific Ocean may have a profound influence on how we model ecosystem processes, including the potential effects of natural or humaninduced environmental change.

Received 4 June; accepted 27 June 1997.

1. Capone, D. G., Zehr, J. P., Paerl, H. W., Bergman, B. \& Carpenter, E. J. Trichodesmium, a globally significant marine cyanobacterium. Science 276, 1221-1229 (1997).

2. Dugdale, R. C., Menzel, D. W. \& Ryther, J. H. Nitrogen fixation in the Sargasso Sea. Deep-Sea Res. 7, 297-300 (1961).

3. Goering, J. J., Dugdale, R. C. \& Menzel, D. W. Estimates of rates of nitrogen uptake by Trichodesmium sp. in the tropical Atlantic Ocean. Limnol. Oceanogr. 11, 614-620 (1966).

4. Carpenter, E. J. Nitrogen fixation by Oscillatoria (Trichodesmium) thiebautii in the southwestern Sargasso Sea. Deep-Sea Res. 20, 285-288 (1973).

5. Mague, T. H., Weare, N. M. \& Holm-Hansen, O. Nitrogen fixation in the North Pacific Ocean. Mar Biol. 24, 109-119 (1974).

6. Carpenter E. J. \& Price, C. C. Nitrogen fixation, distribution, and production of Oscillatoria (Trichodesmium) spp. in the western Sargasso and Caribbean Seas. Limnol. Oceanogr. 22, 60-72 (1977).

7. Howarth, R. W., Marino, R., Lane, J. \& Cole, J. J. Nitrogen fixation in freshwater, estuarine, and marine ecosystems. 1. Rates and importance. Limnol. Oceanogr. 33, 669-687 (1988).

8. Capone, D. G. \& Carpenter, E. J. Nitrogen fixation in the marine environment. Science 217, 1140-1142 (1982).

9. Carpenter, E. J. \& Romans, K. Major role of the cyanobacterium Trichodesmium in nutrient cycling in the North Atlantic Ocean. Science 254, 1356-1358 (1991).

10. Karl, D. M., Letelier, R., Hebel, D. V., Bird, D. F. \& Winn, C. D. in Marine Pelagic Cyanobacteia: Trichodesmium and Other Diazotrophs (eds Carpenter, E. J., Capone, D. G. \& Rueter, J. G.) 219-237 (Kluwer Academic, Dordrecht, 1992).

11. Altabet, M. A., Robinson, A. R. \& Walstad, L. J. A model for the vertical flux of nitrogen in the upper ocean: simulating the alteration of isotopic ratios. J. Mar. Res. 44, 203-225 (1986).

12. Eppley, R. W. \& Peterson, B. J. Particulate organic flux and planktonic new production in the deep ocean. Nature 282, 677-680 (1979).

13. Lewis, M. R., Harrison, W. G., Oakey, N. S., Hebert, D. \& Platt, T. Vertical nitrate fluxes in the oligotrophic ocean. Science 234, 870-873 (1986).

14. Martin, J. H., Knauer, G. A., Karl, D. M. \& Broenkow, W. W. VERTEX: carbon cycling in the northeast Pacific. Deep-Sea Res. 34, 267-286 (1987).

15. Karl, D. M. \& Lukas, R. The Hawaii Ocean Time-series (HOT) Program: Background, rationale and field implementation. Deep-Sea Res. 43, 129-156 (1996).

16. Karl, D. M. HOT and the North Pacific gyre. Nature 378, 21-22 (1995).

17. Trenberth, K. E. \& Hurrell, J. W. Decadal atmosphere-ocean variations in the Pacific. Clim. Dyn. 9 303-319 (1994).

18. Karl, D. M. et al. Ecosystem changes in the North Pacific subtropical gyre attributed to the 1991-92 El Niño. Nature 373, 230-234 (1995).
19. Carpenter, E. J., Capone, D. G. \& Rueter, J. G. (eds) Marine Pelagic Cyanobacteria: Trichodesmium and other Diazotrophs (Kluwer Academic, Dordrecht, 1992).

20. Letelier, R. M. \& Karl, D. M. Role of Trichodesmium spp. in the productivity of the subtropical North Pacific Ocean. Mar. Ecol. Prog. Ser. 133, 263-273 (1996).

21. Carpenter, E. J. Physiology and ecology of marine planktonic Oscillatoria (Trichodesmium). Mar. Biol. Lett. 4, 69-85 (1983).

22. Mitsui, A. et al. Strategy by which nitrogen-fixing unicellular cyanobacteria grow photoautotrophically. Nature 323, 720-722 (1986)

23. Redfield, A. C., Ketchum, B. H. \& Richards, F. A. in The Sea: Ideas and Observations on Progress in the Study of the Seas Vol. 2 (ed. Hill, M. N.) 26-77 (Wiley Interscience, New York, 1963).

24. Goldman, J. C., McCarthy, J. J. \& Peavey, D. G. Growth rate influence on the chemical composition of phytoplankton in oceanic waters. Nature 279, 210-215 (1979).

25. Sakshaug, E. \& Holm-Hansen, O. Chemical composition of Skeletonema costatum (Grev.) Cleve and Pavlova (Monochrysis) lutheri (Droop) Green as a function of nitrate-, phoshate-, and iron-limited growth. J. Exp. Mar. Biol. Ecol. 29, 1-34 (1977).

26. Carpenter, E. J. \& Price, C. C. Marine Oscillatoria (Trichodesmium): Explanation for aerobic nitrogen fixation without heterocysts. Science 191, 1278-1280 (1976).

27. Glibert, P. M. \& Bronk, D. A. Release of dissolved organic nitrogen by marine diazotrophic cyanobacteria, Trichodesmium spp. Appl. Environ. Microbiol. 60, 3996-4000 (1994).

28. Capone, D. C., Ferrier, M. D. \& Carpenter, E. J. Amino acid cycling in colonies of the planktonic marine cyanobacterium Trichodemium thiebautii. Appl. Environ. Microbiol. 60, 3989-3995 (1994).

29. Karl, D. M., Tien, G., Dore, J. \& Winn, C. D. Total dissolved nitrogen and phosphorus concentration at U.S.-JGOFS Station ALOHA: Redfield reconciliation. Mar. Chem. 41, 203-208 (1993).

30. Winn, C. D., Mackenzie, F. T., Carrillo, C. J., Sabine, C. L. \& Karl, D. M. Air-sea carbon dioxide exchange in the North Pacific subtropical gyre: Implications for the global carbon budget. Glob. Biogeochem. Cycles 8, 157-163 (1994).

31. Owens, N. J. P. Natural variations in ${ }^{15} \mathrm{~N}$ in the marine environment. Adv. Mar. Biol. 24, 389-451 (1987).

32. Wada, E. \& Hattori, A. Nitrogen in the Sea: Forms, Abundances, and Rate Processes (CRC, Boca Raton, Florida, 1991)

33. Wada, E. in Isotope Marine Chemistry (eds Goldberg, E. D., Horibe, Y. \& Saruhashi, K.) 375-398 (Uchida Rokakuho, Tokyo, 1980).

34. Björkman, K. \& Karl, D. M. Bioavailability of inorganic and organic phosphorus compounds to natural assemblages of microorganisms in Hawaiian coastal waters. Mar. Ecol. Prog. Ser. 111, 265-273 (1994)

35. Karl, D. M. et al. Seasonal and interannual variability in primary production and particle flux at Station ALOHA. Deep-Sea Res. II 43, 539-568 (1996).

36. Dugdale, R. C. \& Goering, J. J. Uptake of new and regenerated forms of nitrogen in primary productivity. Limnol. Oceanogr. 12, 196-206 (1967).

37. Rueter, J. G., Hutchins, D. A., Smith, R. W. \& Unsworth, N. L. in Marine Pelagic Cyanobacteria: Trichodesmium and other Diazotrophs (eds Carpenter, E. J., Capone, D. G. \& Rueter, J. G.) 289-306 (Kluwer Academic, Dordrecht, 1992)

38. Tersol, V., Vink, S., Yuan, J. \& Measures, C. I. Variations in iron, aluminum and berylium concentrations in surface waters at Station ALOHA. Eos 76, OS65 (1996).

39. Armstrong, F. A., Williams, P. M. \& Strickland, J. D. H. Photo-oxidation of organic matter in seawater by ultraviolet radiation, analytical and other applications. Nature 211, 481-483 (1966).

40. Karl, D. M., Dore, J. E., Hebel, D. V. \& Winn, C. in Marine Particles: Analysis and Characterization (eds Hurd, D. C. \& Spencer, D. W.) 71-77 (Am. Geophys. Un., Washington DC, 1991).

41. Garside, C. A chemiluminescent technique for the determination of nanomolar concentrations of nitrate and nitrite in seawater. Mar. Chem. 11, 159-167 (1982).

42. Karl, D. M. \& Tien, G. MAGIC: A sensitive and precise method for measuring dissolved phosphorus in aquatic environments. Limnol. Oceanogr. 37, 105-116 (1992)

43. Stewart, W. D. P., Fitzgerald, G. P. \& Burris, R. H. In situ studies on $\mathrm{N}_{2}$ fixation using the acetylene reduction technique. Proc. Natl Acad. Sci. USA 58, 2071-2078 (1967).

44. Honjo, S. \& Doherty, K. W. Large aperture time-series sediment traps; design objectives, construction and application. Deep-Sea Res. 35, 133-149 (1988).

Acknowledgements. We thank the HOT Program scientists and staff, and the officers and crew member of the research vessels used in our field work for making this study possible, and E. Laws for comments on the manuscript. This work was supported in part by the National Science Foundation.

Correspondence should be addressed to D.K. (email:dkarl@soest.hawaii.edu). All HOT programme data sets, including the detailed sampling and analytical protocols, are available at http://hahana.soest. hawaii.edu. 